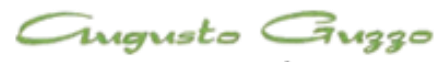

REVISTA ACADEMICA

\title{
A produção de sentido nos textos empresariais
}

\author{
Reginaldo Aparecido Cândido
}

Recebido em: 06/03/2013. Aprovado em: 21/04/2013. Disponibilizado em: 26/06/2013

1. Reginaldo Aparecido Cândido faz parte do corpo de professores e do Grupo de Pesquisa das Faculdades ENIAC. de Guarulhos, São Paulo.

\section{Resumo}

A intenção desse artigo é mostrar um olhar sobre as deficiências da aplicação da Língua Portuguesa no contexto empresarial. Haja vista a complexidade do assunto, essa discussão propõe um estudo de alguns mecanismos de construção do texto empresarial a fim de evidenciar que essa forma textual vai além de uma construção referencial e conteudística. No entanto, entendemos a dificuldade dos alunos e dos colaboradores das empresas em interagir com a linguagem culta e nesse sentido, para tentar vencer o uso inadequado do idioma, propomos um trabalho em que se alicerce na produção de sentido nos textos empresariais.

Palavras-chave: Textos empresariais, produção de sentido, Referencial e conteudística.

\begin{abstract}
The intent of this paper is to show a look at the shortcomings of the application of the Portuguese language within a business context. Considering the complexity of the subject, this discussion proposes a study of the mechanisms of text construction business in order to show that this goes beyond textual reference and a construction of content. However, we understand the difficulty of students and employees of enterprises to interact with the learned language and in that sense, to try wins the inappropriate use of language, we propose a work that underpins the production of meaning in business texts.
\end{abstract}

Keywords: Business texts, Production of meaning, Construction of content. 


\section{Introdução}

Este artigo reporta à aplicação teórica de uma abordagem pedagógica no trato com o texto empresarial, discutindo os mecanismos internos e externos para a compreensão dessa modalidade textual. Para tanto, faz-se necessário uma retomada dos princípios das regras gramaticais para entender os nexos lógicos presentes no idioma. Para esse procedimento, são tomados conceitos dos estudos gramaticais acerca do texto empresarial, apoiada, portanto, em teoria e discussão apropriada. Não se pretende discutir novas utilizações, nem tampouco se prender a nomenclatura técnica do uso das regras da língua. Interessa sim, neste artigo, observar como são apresentadas algumas construções do texto empresarial e como são desenvolvidas e os elementos que a constituem. Seguindo esse raciocínio, a metodologia de análise será a que estuda as estratégias utilizadas para análises textuais que remetem a determinantes internos e externos que são encontrados no texto e os caminhos que podem ser construídos para que se produza sentido no mesmo.

Nesse intuito, pode-se dizer que a falta do hábito de leitura é um dos fatores responsáveis pelo mau uso do idioma, em todos os âmbitos da sociedade. Pois, a cada leitura feita, vai se formando um banco de dados - o conhecimento de mundo - que faz com que se criem facilitadores para o entendimento e a produção textual. Não por acaso, há a falta desse hábito na maioria das pessoas que frequentam cursos de graduação e que trabalham nas empresas. Um dos esclarecimentos para esse fator seria a variedade de formas de comunicação a que essa demanda tem contato, dentre elas, a comunicação oral e visual. Partindo dessa premissa, as gerações contemporâneas convivem cada vez mais com uma cultura baseada em diferentes discursos, cria-se um quadro que predispõe diferenças no modo de percepção, também diferenças no modo de conceber e de interagir com o mundo que vão além da leitura do livro, como é o caso das mídias, por exemplo, a televisiva.

Desse modo, é possível pensar que parte das estruturas cognitivas, aquelas que ajudam a entender, a situar-se e se portar diante do mundo, não se modifiquem sensivelmente, e que bastariam ajustes (aprimorados a partir da experiência), para que houvesse plena adaptação a um universo que hoje se pauta a esses diversos discursos, com o objetivo de incentivar o uso adequado da Língua Portuguesa. Ora, o texto empresarial, por ser estritamente escrito, exige total compromisso com o uso adequado do idioma, para facilitar e efetivar a comunicação. Infelizmente, essas gerações chegam às empresas com deficiências comunicativas tanto na fala como na escrita.

$\mathrm{Na}$ sala de aula, os professores se deparam com grandes lacunas no que diz respeito à questão metodológica do enfrentamento dos aspectos gramaticais sejam sintáticos, sejam semânticos - de um texto, principalmente no contexto empresarial aqui mencionado. Totalmente compreensível esse panorama, pois a maioria das pessoas são fortemente influenciadas pela cultura oral, que, no entanto, difere daquela efetuada nos meios empresariais, porque prezam pela linguagem formal, isto é, uma construção escrita, por ser mais efetiva quando se trata da execução de ações.

Sendo assim, o objetivo aqui não é somente apontar as dificuldades de se elaborar um texto empresarial, mas incentivar a capacidade de compreensão das estruturas internas, presentes no texto, que garantem os sentidos para o entendimento dessa comunicação empresarial. 


\section{A Comunicação Empresarial}

Segundo Mirian Gold ${ }^{1}$, o moderno texto empresarial surgiu no final da década de 70 , por causa do contexto econômico e da competitividade. Havia uma necessidade de se fazer uma redação mais objetiva, direcionada à qualidade e à fidelização dos clientes. E, principalmente, gerar uma resposta ao que se está transmitindo, propiciando uma ação.

A eficácia do texto empresarial moderno equivale à força da retórica clássica. Na Antiguidade, o discurso retórico continha uma função expressiva e persuasiva consagrada pelos oradores. Hoje em dia, o meio empresarial gasta fortunas em marketing direto, esquecendo-se de usar em seu texto recursos que se configuram como arma preciosa no relacionamento com o cliente, seja ele interno ou externo ${ }^{2}$.

Nesse sentido, a Comunicação Corporativa é considerada ferramenta fundamental para o desenvolvimento e o crescimento de qualquer organização, funcionando como um elo entre a comunidade e o mercado. E uma comunicação eficiente traz resultados que podem ser medidos no faturamento da empresa. Como afirma a autora: A velocidade com que o mundo corporativo cresce e se transforma é outro ponto que concede destaque à escrita. Uma vez que a correta padronização estética e a apresentação objetiva contribuem para uma comunicação ágil e precisa. Por isso, é importante que os documentos empresariais transmitam suas mensagens com clareza ${ }^{3}$.

Exemplos simples de verbosidade excesso de palavras - no texto podem provocar grandes ruídos na efetivação da

${ }^{1}$ GOLD, Mirian. Redação Empresarial. 4ed. São

Paulo: Pearson Prentice Hall, 2010.p.5

${ }^{2}$ idem. p.6

${ }^{3}$ Idem p.8 mensagem, ou seja, a redação empresarial deve primar pela simplicidade e precisão vocabular. $\mathrm{O}$ conteúdo da informação e o receptor devem ser a principal preocupação do emissor, por isso recomenda-se o uso de frases curtas, sem muitos adjetivos e uso de palavras e expressões simplificadas em vez de parágrafos de difícil interpretação como este: "Sem mais que se nos possa acrescentar para o momento, despedimo-nos e deixamonos à disposição para o que for necessário na obtenção do desiderato colimado." Portanto, é ponderável que se use construções sintáticas de fácil compreensão, sem precisar de um bom dicionário a tiracolo.

O grande desafio, das empresas hoje, é aprimorar a capacidade dos funcionários no bom uso da linguagem. Essa defasagem é consequência das deficiências na Educação Básica do País. Diante disso, temos um cenário com poucas mudanças, pelo baixo investimento no setor. Há também, uma grande lacuna entre a linguagem formal utilizada nas empresas - em relação à informal, que faz parte do cotidiano desse público, ou seja, há uma proximidade da fala e, muitas vezes, ela é reproduzida na forma escrita, ocasionando ruídos na comunicação empresarial.

\section{A clareza do texto e a comunicação}

Quando se fala em comunicação, a primeira ideia que vem à mente é a de transmissão de uma informação para alguém, isto é, um ato interacional que pode ser por meio de conversa, e-mail, imagens e até gestos. O espaço ocupado pelo texto empresarial, predominantemente escrito, não pode ser desprezado, pois leva a uma ação que só ocorrerá se a comunicação for atingida na sua plenitude.

Todas essas formas de comunicação, no entanto, são muito mais do que a difusão de 
informações entre sujeitos do processo comunicacional. Comunicar é, antes de tudo, persuadir. Em outras palavras, quase todo ato de comunicação, seja simples ou mais complexo pressupõe um sujeito que quer induzir outro a crer em alguma coisa. São os discursos que envolvem o ato interacional, trazendo junto deles uma intenção que permeia o objetivo de toda empresa: mensagem clara que leve a uma ação. Ora, a comunicação empresarial está impregnada de persuasão - o ato de levar o outro a aceitar o que está sendo dito - porque só quando ele realizar a ação desejada é que se poderá dizer que a comunicação foi eficaz.

Para que exista uma comunicação bemsucedida, um autor precisa levar em consideração as expectativas e as prováveis reações de quem vai receber o texto. É necessário fazer uma adequação vocabular, ou seja, conhecer o público a que está direcionada a comunicação, só assim irá construir um discurso com a eficiência desejada:

\begin{abstract}
Se o sujeito falante pode produzir/interpretar um número infinito de discursos diferentes, sua competência é necessariamente uma competência textual. É muito pouco provável, e mesmo impossível, que a produção e a percepção de enunciados textuais se operem por uma concatenação não regrada de frases isoladas. A própria noção de coerência seria inexplicável numa tal concepção ${ }^{4}$. ( GUIMARÃES, Elisa. A articulação do texto. São Paulo: Ática, 2004. p. 19).
\end{abstract}

Nesse sentido, por exemplo, um aviso na empresa apenas surtirá efeito se todos os envolvidos reproduzirem em sua mente a mesma imagem - uma mensagem deverá ser compreendida da mesma forma por todos os envolvidos, ou seja, deve haver uma isotopia de pensamento. Também, se uma carta empresarial contém erros de ortografia, ambiguidades e argumentação ruim pode prejudicar a credibilidade do produtor do texto, além do mau entendimento por parte do receptor.

Assim, um dos grandes desafios encontrados na comunicação empresarial é fazer com que o autor dessa mensagem a torne clara. Em muitos textos percebemos que a escolha vocabular não prioriza $o$ público alvo, mas sim o uso de expressões rebuscadas ou chulas demais que, em muitos casos, prejudicam a efetivação da comunicação. Como no caso citado a seguir, de uma forma em que o emissor da carta utiliza palavras que não condizem com o receptor, isto é, inadequação vocabular:

${ }^{4}$ GUIMARÃES, Elisa. A articulação do texto. São

Paulo: Ática, 2004. p. 19. 
Ilmo. Srs.

J.J. Martins

Caixa Postal 974

Curitiba - PR

Prezados Senhores:

Desejamos acusar o recebimento do seu prezado favor datado de 12 de outubro próximo passado, junto ao qual V.Sas. tiveram a gentileza de nos encaminhar os documentos relativos às mercadorias por nós encomendadas.

Informamos, outrossim, que as mercadorias em referência chegaram em perfeitas condições, nada nos sendo lícito reclamar nesse sentido. Lamentamos, no entanto, ter de externar-lhes a nossa estranheza ante o fato de constar, na fatura que nos foi remetida por V.Sas., vencimento para 30 dias, quando o que havia combinado com o representante de sua conceituada empresa foi de 90 dias.

Solicitamos, pois, esclarecimento a respeito, deixando claro que não poderemos aceitar a duplicata, caso não nos seja concedido o prazo previamente combinado.

Cientes de que esta nossa justa pretensão será acolhida por V.Sas., firmamo-nos com estima e apreço.

MERCANTIL TEIXEIRA \& CIA

JOSÉ LINS

Diretor $^{5}$

${ }^{5}$ GOLD, Mirian. Redação Empresarial. 4ed. São Paulo: Pearson Prentice Hall, 2010.p.22. 


\section{Características do texto empresarial}

Não há como contestar a importância e a eficácia do bom texto empresarial. $\mathrm{O}$ texto empresarial é técnico. Existem regras que determinam os preceitos básicos de como tornar o discurso empresarial mais persuasivo e eficaz. Em um mundo globalizado, não basta transmitir a ideia, tem que ser compreendido para que a ação possa ser executada. Acerca dessa discussão, serão arroladas a seguir algumas características do texto empresarial da autora Miriam Gold .

a) Concisão: máximo de informações com o mínimo de palavras. O texto bem escrito e que pretende ser conciso será aquele em que todas as palavras e informações utilizadas tenham uma função significativa.

b) Objetividade: quando se fala em objetividade, é saber definir quais as informações relevantes que se deseja transmitir naquele momento.

c) Clareza: a causa de a clareza ser uma das características mais difíceis de ser obtida é o fato de que para quem escreve, a ideia já está clara em sua mente. Assim, ele não percebe as falhas ou lacunas de sentido que possa haver entre o que pensa e o que escreve. Como no exemplo, que mostra uma ambiguidade. "Pedro e Paulo vão se separar".

d) Coerência: é o encadeamento lógico entre as ideias, que se faz principalmente mediante as relações de tempo, espaço, causa e consequência.

e) Linguagem formal: as situações linguísticas são muito complexas. Em um panorama sucinto das duas principais variações temos o dialeto e o registro. $\mathrm{O}$ dialeto é a variação de uma língua dentro de um espaço geográfico; registro é o ajuste da língua mediante a situação contextual e do destinatário.

f) Adequação Vocabular: $O$ léxico está repleto de palavras, imaginemos um conjunto de palavras que representem todas as palavras do idioma, cabe ao autor do texto lançar mão das melhores palavras para o público alvo desejável. Ele deve evitar construções muito rebuscadas e técnicas, por exemplo, para pessoas com pouca instrução.

\section{Esquema de construção do texto}

Um texto deve ter coerência, ou seja, um sentido global compreendido pelo leitor. Isso quer dizer que não é uma soma de frases amontoadas sobre um determinado assunto. Trata-se, na verdade, de um conjunto de partes interdependentes que objetivam um amplo entendimento do assunto ali tratado. Um autor, antes de escrever, precisa ter na mente a clareza do que se quer transmitir ao papel, o que se quer comunicar. Aliás, do próprio objetivo do texto, pois um texto bem compreendido é um texto escrito de forma clara. Nesse sentido, com a ideia na cabeça, o autor passa a pensar de que forma deve organizar seu pensamento, a fim de montar seu texto sem prejudicar o leitor, fazendo uso de um vocabulário adequado, claro e com a ausência de discrepâncias.

Um texto também precisa ter começo, meio e fim, com suas partes perfeitamente encadeadas. Há um esquema clássico. $\mathrm{Na}$ primeira parte, existe uma introdução da ideia.

Depois, um desenvolvimento do assunto, em que mais detalhes são apresentados. E, por fim (literalmente), há uma conclusão. Parece simples. Na verdade, não é. Quanto mais complexo for o tema do trabalho, mais difícil se torna essa organização. Além disso, como o texto é a 
materialização do discurso e ele precisa ter força persuasiva, principalmente nas empresas. Algumas dicas de construção textual podem também ajudar a tornar o texto mais atrativo.

Nesse esquema de construção textual, introdução, desenvolvimento e conclusão, é comum o autor começar enunciando um fato de forma generalizada, dar mais detalhes e fazer uma proposta ou uma análise mais incisiva no desenvolvimento e na conclusão a reafirmação desse pensamento. A conclusão aparece, assim, como um dos pontos mais fortes do texto. Só que um leitor só vai tomar conhecimento desse fato se ler o texto inteiro. A melhor maneira de obter a atenção é começar precisamente com a informação ou comentário mais forte para provocar uma curiosidade no destinatário.

No texto empresarial, o documento é sempre redigido para um leitor (interno ou externo) visando uma resposta ou ação. Se a ação ou a resposta for a que se espera o texto foi eficaz, se não, o texto deve ser repensado e reescrito.

\section{Coesão}

Assim como a coerência assume fundamental importância na construção textual, a coesão também é um recurso essencial à boa expressão escrita.

De acordo com $\mathrm{Koch}^{6}$, a coesão constitui uma espécie de conexão que se estabelece entre os elementos textuais. Ela é importante porque favorece o entrelaçamento das ideias, evitando a ocorrência de frases soltas, sem ligação entre si. O uso de elementos coesivos dá ao texto mais legibilidade, explicitando os tipos de relações estabelecidas entre os elementos linguísticos - artigos, preposições,

${ }^{6} \mathrm{KOCH}$, Ingedore. A coesão textual. São Paulo: Contexto, 1999. conjunções, entre outros - que o compõem. Em muitos tipos de textos (científicos, didáticos, expositivos e opinativos, por exemplo) a coesão é altamente desejável como mecanismo de manifestação de coerência, incorporando o sentido no texto.

Também como parte desses componentes de conexão tem-se a pontuação. Se uma redação não recebeu uma boa pontuação perde-se inteligibilidade, o texto passa a apresentar irregularidades, ou seja, problemas relacionados à coesão. Por exemplo, uma construção de e-mail em que exige uma resposta bem pontual e contextualizada. Como numa situação em que um gerente de uma empresa está em reunião com um cliente para se fechar um negócio. Simultaneamente, o gerente está conectado com um diretor, que por e-mail está tomando a decisão do acordo. Conectado, o gerente cumpre as ordens delegadas a ele. Então, o gerente escreve ao Diretor a seguinte pergunta:

"Assino o contrato ou espero a próxima reunião?" E o Diretor lhe dá a seguinte resposta:

"Não assina o contrato".

Diante dessa resposta, o gerente combina com o cliente um próximo encontro. Chegando à empresa, o Diretor lhe pergunta como foi a assinatura do contrato. O gerente não entende a indagação do Diretor, já que o e-mail dizia justamente o contrário, que não era para assinar o contrato.

Por falta de uma vírgula, muitas empresas perdem contratos e muito dinheiro. Nesse sentido, o Diretor deveria ter colocado a vírgula assim:

"Não, assina o contrato", para que o negócio fosse concretizado.

Com esse fato, pode-se dizer que os emails são um grande foco de preocupação 
em algumas empresas. Com o uso cada vez mais intenso deles, tanto interno como externamente. O funcionário representa a empresa, isto é, o bom texto representa a empresa. Com essa premissa, se ele se comunica mal, ele representa mal a empresa. Nota-se hoje, muitos cursos para o aprimoramento da comunicação institucional e o esforço das empresas para aprimorar a capacidade dos funcionários no uso da linguagem. Isso demanda das deficiências na Educação Básica do País.

\section{7 - Considerações Finais}

Este trabalho apresentou algumas reflexões a respeito da importância da construção de um texto, baseada no sentido que o autor proporciona ao leitor. Sob a ótica da linguística textual e de alguns estudos a respeito da redação empresarial, a análise de algumas situações em que alunos e funcionários de empresas constituem a tessitura de seus textos. Sabe-se que a coesão e a coerência textual garantem a textualidade, porém fica evidente a dificuldade de algumas pessoas quanto ao uso dos conectores, inclusive a pontuação.

Esse artigo foi pensado, a partir da experiência docente com alunos oriundos de algumas empresas, de diversos segmentos, que iniciaram a graduação em 2011. Tendo como análises produções textuais desses alunos na sala de aula, textos estes, sempre voltados ao âmbito empresarial. $\mathrm{O}$ artigo foi produzido como um viés para se abrir uma discussão futura, com o intuito de encontrar mecanismos que sanem algumas dificuldades de produção textual, que acontecem, dentre muitos outros fatores, por causa de uma sociedade que não tem o hábito de leitura e de uma educação básica deficiente.

Assim, esse artigo pode servir de propulsor para a reflexão acerca da arquitetura textual, a fim de que os textos empresariais possam ser aprimorados e que seus produtores possam ter mais afinidade com relação à estrutura e a produção de sentido nos textos.

\section{Referências Bibliográficas}

1. ABREU, Antônio Suárez. Curso de redação. 10. ed. São Paulo: Ática, 1999.

2. BLIKSTEIN, Izidoro. Técnicas de comunicação escrita. 11. ed. São Paulo: Ática, 1993.

3. DISCINI, Norma, e TEIXEIRA, Lúcia. Leitura do Mundo. São Paulo: Ed. Brasil. $\mathrm{s} / \mathrm{d}$.

4. FARACO, C; MOURA, F. Para gostar de escrever. 11.ed. São Paulo: Ática, 1997.

5. GARCIA, Othon Marques. Comunicação em prosa moderna. 14. ed. Rio de Janeiro: Fundação Getúlio Vargas, 1988.

6. GOLD, Mirian. Redação Empresarial. 4ed. São Paulo: Pearson Prentice Hall, 2010.

7. GUIMARÃES, Elisa. A articulação do texto. São Paulo: Ática, 2004.

8. KOCH, Ingedore. A coesão textual. São Paulo: Contexto, 1999.

9. MARTINS, Eduardo. Manual de Redação e Estilo - O Estado de São Paulo. 3a . Ed. São Paulo: O Estado de São Paulo, 1997.

10. PLATÃO, Francisco Savioli; FIORIN, José Luiz. Para entender o texto: leitura e redação. 7. ed. São Paulo: Ática, 1993. Lições de texto: leitura e redação. São Paulo: Ática, 1996.

11. NASSAR, Paulo. O que é Comunicação empresarial / Rubens Figueiredo. São Paulo: Brasiliense, 1995. 